\title{
Principales estereotipos femeninos en la publicidad radiofónica española
}

Eva María Gil Benítez y Susana Guerrero Salazar. Madrid, Editorial Fundamentos, 2016, 222 páginas.

\section{Reseña por Laura Pacheco Jiménez}

http://dx.doi.org/10.12795/AdMIRA.2017.01.10

De un lado, Eva María Gil Benítez, doctora por la Universidad de Málaga con su tesis Mujeres y hombres en el discurso publicitario radiofónico (2004-2010), experta en Género e Igualdad de Oportunidades y ganadora del premio Leonor de Guzmán de Estudios de Género por El androcentrismo en la publicidad radiofónica; y, de otro lado, Susana Guerrero Salazar, doctora en Filología Hispánica que recibió en 2004 un reconocimiento por el Instituto de la Mujer por su labor en pro de la igualdad, son respaldo más que de sobra para el libro Principales estereotipos femeninos en la publicidad radiofónica española, un texto que analiza en profundidad los valores más arcaicos que, en pleno siglo XXI, sigue mostrando un medio de comunicación de masas tan importante como es el radiofónico y en un terreno tan resbaladizo como es la publicidad.

A priori, el discurso publicitario radiofónico, puede considerarse con menos potencia que otros mensajes sustentados en imágenes como puede ser la televisión. Sin embargo, lo que puede parecer inofensivo por esta falta de apoyo visual, convierte al discurso radiofónico en un audaz y sigiloso ejercicio que difícilmente puede ser denunciado ante autoridades debido a las situaciones habituales en las que se escucha la radio. Por lo general, los radioyentes comparten su afición con otras tareas cotidianas -conducir, las tareas del hogar, etc-, por lo que la atención es fluctuante y los mensajes pasan más o menos desparecidos en una atención primaria, por el contrario, sí que llegan al subconsciente los modelos y patrones que se transmiten cuña tras cuña. Es por esto que la posibilidad que tiene todo oyente de denunciar cualquier contenido radiofónico se queda a medias tintas, en parte por la escasa atención y en parte por la precisión que piden los organismos a la hora de llevar a cabo la demanda. A esto, hay que sumarle la dificultad que entraña el medio radiofónico para llevar a cabo una investigación exhaustiva sobre sus espacios publicitarios que, en ocasiones se insertan dentro de los propios programas contenedores, por lo que la búsqueda y 
documentación hace de un estudio de estas características un proceso con unos hándicaps concretos.

En este panorama nace esta investigación que ha llevado a sus autoras desde el año 2004 hasta el 2010 por un proceso de análisis, categorización y comparación que no solo les ha permitido una tipología precisa de los principales estereotipos femeninos en la publicidad, sino que, además, tiene como aliciente haber sabido ponderar las variaciones de estereotipos a lo largo de los seis años del estudio, por lo que el lector puede hacerse una idea muy clara de en qué aspectos la publicidad radiofónica mejora o maquilla- sus cuñas y qué asignaturas sigue teniendo pendiente.

Tras una breve introducción sobre las características del estudio, el libro pasa directamente a Roles y estereotipos en el ámbito privado, donde se desglosan las diferencias entre la posición de madre y la de padre, cómo son retratados mujeres y hombres en relaciones de pareja, la representación de la infancia y dos temas de altísimo interés como son las conexiones establecidas por la publicidad -y la sociedadentre: mujer y belleza, y mujer y salud. Es necesario aquí resaltar algunas anotaciones de las autoras como el hecho, por ejemplo, de que las relaciones de pareja se refieren en el $100 \%$ de los casos a relaciones heterosexuales o que se utilice el humor, en este y otros bloques, para menoscabar la imagen de la mujer en cualquiera de los roles en los que esté representada. Además, este capítulo, nos deja cuestiones tan interesantes como las distinciones entre ambos géneros cuando representan a figuras expertas, donde ellos aparecen con cargo, nombre y apellidos, y ellas simplemente con su nombre. Este último, que si bien es un acto sutil, es muy revelador en cuanto a las diferencias de tratamiento por género. Por último, se establecen diferencias en el trato de dos temáticas que, a priori, deberían ser similares, como son la disfunción eréctil -tratada con tintes humorísticos- y la menopausia -donde se enfatiza un tono bastante más severo-.

En el tercer capítulo se analizan los Roles y estereotipos en el ámbito público como son los casos que afectan a las profesiones más feminizadas y a las masculinizadas, tanto desde el propio lenguaje, como desde el discurso radiofónico, que parece estar empeñado en hacer acuñar términos como secretaria y mecánico para dejar claro a qué genero pertenece cada puesto de trabajo. Además, se abordan temáticas como la representación de la compradora compulsiva y sus diferencias con el comprador 
compulsivo -este último afronta compras de mayor carga económica-, o la representación de la mujer en espacios de ocio que, por cierto, es uno de los temas en los que la publicidad radiofónica de los últimos años ha avanzado en mayor medida. Igualmente, se analizan a las mujeres conductoras -quienes necesitan coches de características diametralmente opuestas a ellos-, a mujeres vecinas que, de nuevo, parece ser uno de los roles más superados, o la aparición de las féminas en cuñas relacionadas con ONGs.

Gil y Guerrero no desperdician la ocasión para, en un cuarto capítulo, poner ejemplos de buenas prácticas publicitarias o, en muchos casos, buenas intenciones que, si bien no siempre son igualitarias, muestran que hay un camino abierto que muchos publicistas intentan seguir, aunque sea en busca de un cambio en la imagen social de la marca.

Por último, antes de un completísimo anexo y la bibliografía, se describen las conclusiones del estudio pormenorizadas bajo el título de cada epígrafe tratado a lo largo del libro, por lo que se enumeran a la perfección los roles en los que la mujer ha de oírse representada y los estereotipos que, día a día, hacen de la radio un espacio publicitario conservador que perpetúa modelos tradicionalistas.

En definitiva, el trabajo de las autoras es encomiable, un análisis exhaustivo, un estudio que aúna lo cualitativo y lo cuantitativo para retratar a la perfección la calidad de la publicidad radiofónica de nuestro país en lo que a género se refiere.

\section{$\Gamma \neg$ Grupo de Investigación A. AdMIRA \\ Análisis de Medios, Imágenes y Relatos Audiovisuales}

